\title{
A terhességi cukorbetegség rövid története, kockázati tényezői és diagnosztikája napjainkban
}

\author{
Al-Aissa Zahra dr. ${ }^{1}$ - Hadarits Orsolya dr. ${ }^{2}$ - Rosta Klára dr. ${ }^{2,5}$ \\ Zóka András dr. ${ }^{4}$ - Rigó János Jr. dr. ${ }^{2}$ \\ Firneisz Gábor dr. ${ }^{1,3}$ - Somogyi Anikó dr. ${ }^{1}$ \\ Semmelweis Egyetem, Általános Orvostudományi Kar, ${ }^{1}$ II. Belgyógyászati Klinika, \\ ${ }^{2}$ Szülészeti és Nőgyógyászati Klinika, Budapest \\ ${ }^{3}$ MTA-SE Molekuláris Medicina Kutatócsoport, Budapest \\ ${ }^{4}$ Szent István és Szent László Kórház-Rendelőintézet, Budapest \\ ${ }^{5}$ Bécsi Orvostudományi Egyetem, Szülészeti és Nőgyógyászati Klinika, Bécs
}

\begin{abstract}
A cukorbetegség az egyik leggyakoribb anyagcserezavar, amely hozzájárulhat patológiás terhesség kialakulásához. A terhesség alatt felismert diabetes mellitus kezelése csökkenti az anyai és magzati komplikációkat. A gestatiós cukorbeteg terhesek kockázata fokozott az extrém súlynövekedésre, praeeclampsiára, császármetszésre, 2-es típusú diabetes és cardiovascularis betegségek későbbi kialakulására. Gestatiós diabeteses anyák magzataiban gyakrabban jelentkezik macrosomia, születés alatti traumás sérülés, születésük után pedig hypoglykaemia, hyperbilirubinaemia, idiopathiás respirációs distressz szindróma. A terhességi cukorbetegség diagnosztikájára nincs konszenzus a különböző, diabetesszel foglalkozó szervezetek ajánlásaiban. Orv. Hetil., 2017, 158(8), 283-290.
\end{abstract}

Kulcsszavak: gestatiós diabetes mellitus, Hyperglycemia and Adverse Pregnancy Outcome (HAPO), orális glükóztolerancia-teszt

\section{A brief history of gestational diabetes mellitus, risk factors and current criteria of diagnosis}

Diabetes is one of the most common metabolic disorders that may cause pathological pregnancy. Treating diabetes recognized during pregnancy results in lowering maternal and fetal complications. These patients present higher risk for excessive weight gain, preeclampsia, delivery with cesarean sections, high risk of developing type 2 diabetes and cardiovascular disease in the future. Fetuses of mothers with gestational diabetes are at higher risk for macrosomia and birth trauma, after delivery they present higher risk of developing neonatal hypoglycemia, hyperbilirubinemia, and respiratory distress syndrome. There is still no consensus in the recommendations for the diagnosis of gestational diabetes mellitus by expert committees.

Keywords: gestational diabetes mellitus (GDM), Hyperglycemia and Adverse Pregnancy Outcome (HAPO), oral glucose tolerance test (OGTT)

Al-Aissa, Z., Hadarits, O., Rosta, K., Zóka, A., Rigó, J. Jr., Firneisz, G., Somogyi, A. [A brief history of gestational diabetes mellitus, risk factors and current criteria of diagnosis]. Orv. Hetil., 2017, 158(8), 283-290.

(Beérkezett: 2016. október 27.; elfogadva: 2016. december 16.)

\section{Rövidítések}

$\mathrm{ADA}=($ American Diabetes Association) Amerikai Diabetes Társaság; CDKALl = CDK5 regulatory subunit associated protein 1-like 1; GCK = glucokinase; GDM = gestatiós diabe- tes mellitus; HAPO (vizsgálat) = Hyperglycemia and Adverse Pregnancy Outcome; IADPSG = (International Association of Diabetes and Pregnancy Study Groups) Diabeteses Terhességgel Foglalkozó Munkacsoportok Nemzetközi Szövetsége; IDF 
$=($ International Diabetes Federation $)$ Nemzetközi Diabetes Szövetség; IFG = (impaired fasting glucose) emelkedett éhomi vércukorszint; IGF2BP2 = insulin-like growth factor 2 mRNAbinding protein 2 ; IGT $=$ (impaired glucose tolerance $)$ csökkent glükóztolerancia; IRS1 = insulin receptor substrate 1 ; $\mathrm{KCNJII} \mathrm{=} \mathrm{potassium} \mathrm{voltage-}$ gated channel subfamily J member 11 ; KCNQ1 = potassium voltage-gated channel subfamily Q member 1; MDT = Magyar Diabetes Társaság; MNT = (medical nutrition therapy) orvosi táplálkozásterápia; MTNRIB = melatonin receptor $1 \mathrm{~B}$; NDDG $=$ National Diabetes Data Group; NICE $=($ National Institute for Health and Clinical Excellence) Nemzeti Intézet az Egészségért és a Klinikum Kiválóságáért; NIH = (National Institutes of Health) Amerikai Nemzeti Egészségvédelmi Intézet; NPH-inzulin = neutral protamine hagedorn inzulin; OGTT $=$ (oral glucose tolerance test $)$ orális glükóztolerancia-teszt; PCOS = polycystás ovarium szindróma; $\mathrm{PGDM}=$ praegestatiós diabetes; TCF7L2 = transcription factor 7-like 2; WHO = (World Health Organization) Egészségügyi Világszervezet

A cukorbetegség a XXI. század egyik legjelentősebb egészségügyi problémája. A diabetes és szövődményei a legtöbb országban a vezető halálokok között vannak. Az Egészségügyi Világszervezet (World Health Organization - WHO) becslése szerint a magas vércukorszint a korai halandóság harmadik kockázati tényezője, a magas vérnyomás és a dohányzás után. A cukorbetegség globális prevalenciája 1980 óta megkétszereződött, 4,7\%-ról 8,8\%-ra növekedett a felnőtt népesség körében (108 millió 1980-ban, 422 millió diabeteses 2014-ben). Világviszonylatban, az incidenciát szem előtt tartva, éves szinten ez 10 millió új esetnek felel meg. A Nemzetközi Diabetes Szövetség (International Diabetes Federation - IDF) adatai szerint 2015-ben 20,9 millió élveszületés (16,2\%) szövődött terhesség alatti hyperglykaemiával. A terhességet megelőzően diagnosztizált diabetes a praegestatiós diabetes (PGDM), amely a fogamzóképes korú nők körében előforduló diabetes 7,5\%-át képezi. Az érintettek döntő hányada, $85,1 \%$-a gestatiós diabetes mellitusban (GDM) szenved. A gestatiós diabetes mellitus a terhesség alatt kialakult vagy felismert szénhidrátanyagcsere-zavar $[1,2]$.

\section{A gestatiós diabetes mellitus prevalenciája}

Magyarországon 2003 és 2015 között a gyermekek és felnőttek körében egyaránt megkétszereződött a cukorbetegség előfordulásának gyakorisága. Átlagosan a terhességek 1-14\%-a szövődik GDM-mel, a legfrissebb magyar vizsgálat becslése szerint hazánkban a GDM prevalenciája 8,1-14,8\% közötti [1-4].

A GDM magyarországi előfordulásának alakulását régóta számos munkacsoport követi. Winkler és mtsai által 1995-ben végzett szúrés eredménye 7,5\%-os GDMgyakoriságot mutatott [5]. Egyed és mtsai 1996-ban a gestatiós diabetesesek szüléseinek számát 2000-2500 körülinek találták [6]. Pátkay és mtsai 10 éves dunaújvá- rosi szürési adatokat ismertetve a GDM prevalenciáját 3\% körülinek írták le, 1,7-4,1\% közötti éves ingadozással [7]. Baranyi és mtsai 1998-ban a gestatiós diabetesszel szövődött terhességek számát 2000-3000-re becsülték [8]. Kerényi és mtsai a budapesti Szent Imre Kórházban egyéves követés során $5,3 \%$-os, hároméves követés során 6,4\%-os gyakorisággal diagnosztizáltak GDM-et a várandósok szưrése során [9]. Kun és mtsai Tolna megyében 2013 terhesen végzett orális glükózterhelés (OGTT) alapján 8,6\%-os incidenciát írtak le [10]. Korábbi hazai adatok szerint a gestatiós diabetes elófordulása 1,7-7,9\% közötti, egy másik, validáltan teljes körű szürés eredménye alapján incidenciája $6,4 \%[11,12]$.

A fogamzókorú nóknél, az obesitas növekedésével párhuzamosan, növekszik a GDM incidenciája, hét terhességból egyben jelentkezik a kórkép [2]. A legújabb vizsgálatok alapján elmondható, hogy a gestatiós diabetes mellitus előfordulási gyakorisága 10-100\%-kal nőtt az utóbbi 20 évben [13]. Kínában az Amerikai Diabetes Társaság (American Diabetes Association - ADA) által elfogadott GDM diagnosztikus kritériumokat alkalmazva 2,9\%-os prevalenciáról számoltak be. Yang és mtsai a terhesség alatti kóros szénhidrát-anyagcsere 7,3\%-os incidenciáját írták le, és fokozatos növekedését figyelték meg 1995 és 2004 között [14]. A GDM-prevalencia és -incidencia ilyen mértékü növekedésének fontos egészségügyi hatásai vannak a szülőnőkre és utódaikra nézve, akik kezelés nélkül a méhen belüli magzati hyperglykaemiával szemben védtelenek.

\section{A gestatiós diabetes mellitus diagnózisának és szürésének története}

A cukorbetegség évezredek óta ismert betegség, azonban a terhesség alatt jelentkező formáját a XIX. században azonosították. A cukorbetegségről már az egyiptomi Ebers-papirusz is említést tesz az i. e. XVI. században (i. e. 1550). Az el-Lahun-papirusz az i. e. XIX. században (i. e. 1825 ) részletesen beszámol a kor születésszabályozó módszereirôl, a szülés folyamatának ismeretérôl.

A terhességi cukorbetegség első említése Bennewitz De diabete mellito, graviditatis symptomate címmel 1824-ben, Berlinben publikált orvosi tézisében olvasható, amelyben klinikai esetet mutat be: egy nő három egymást követő terhessége során jelentkezett nagyfokú szomjúság és ismétlődő glükózuria, s az egyik gyermeke $5,5 \mathrm{~kg}$ testsúllyal született. A vizeletéből nagy mennyiségü cukrot mutattak ki. Lever 1847-ben, Londonban egy hasonló esetet közölt a Guy’s Kórház Klinikai Közlönyében [15].

Duncan 1882-ben, Londonban számol be 16 nóbeteg 22 terhességéről. Magas arányban fordult elő anyai és perinatalis halálozás: az anyák több mint 60\%-ában és az újszülöttek 47\%-ánál. A terhességek megfigyelésével a következő megállapításokat és következtetéseket vonta le:

- cukorbetegség kialakulhat terhesség alatt, 
- cukorbetegség előfordulhat csak a terhesség ideje alatt,

- a cukorbetegség a terhesség befejeztével megszünhet, és a szülést követően valamikor visszatérhet,

- cukorbetegség kialakulhat a szülést követően,

- terhesség előfordulhat cukorbetegség mellett is,

- a terhesség és szülés folyamatát látszólag nem befolyásolja a cukorbetegség,

- a terhességet gyakran megszakítja a magzat halála [16].

Williams, baltimore-i szülész-nőgyógyász professzor 1909-ben 66 irodalmi esetet foglalt össze. Ötvenöt beteg a teherbe esést megelőzően cukorbeteg volt, kilenc betegnél a teherbe esést követően alakult ki cukorbetegség, és két esetben a betegség kezdete bizonytalan volt. Az anyai halálozási arányok magasak voltak: $27 \%$ körüli a szülés idején, további 23\% két évvel a szülést követően, a perinatalis mortalitási arányok 27-53\% között változtak. Kéziratának középpontjában a terhességi glükózuria értelmezése és diagnosztikus szerepe állt, mivel abban az időben a cukorbetegség diagnózisa a vizeletben megjelenő cukor alapján történt. Kimutatta, hogy a vizeletben 1-3 g/l között előforduló cukor terhesekben fiziológiás állapot, de magasabb koncentráció cukorbetegségre utal, különösen kora terhességben és tünetek jelentkezésével egyidejüleg. A tanulmánya a terhességi cukorbetegség első prospektív szû́rőprogramja lehetett volna [16].

$\mathrm{Az}$ inzulin felfedezése előtt a terméketlenség közismert volt a cukorbeteg nők körében. A feltételezett terméketlenségi okok között amenorrhoea, méh- és Graaftüsző-atrophia, valamint alultápláltság szerepelt [17]. Az inzulin felfedezését és 1923-ban alkalmazásának bevezetését követően a terhességek aránya hétszeresére nőtt a rövid ideje diagnosztizált cukorbeteg nők körében.

Az 1940-1950-es években megfigyelték, hogy a 2-es típusú cukorbeteg nók korábbi terhességei során gyakoribb volt a perinatalis halálozási arány és a nagy magzati súly. Ezen felismerést követően a kutatók a vércukorszintet a terhességi kimenetellel és a hosszú távú anyai cukorbetegség kialakulásának kockázatával kapcsolatban tanulmányozták nem cukorbeteg várandós nők körében.
Jørgen Pedersen epidemiológus 1952-ben elsőként posztulálta az anyai hyperglykaemia hatására kialakuló magzati hyperglykaemia és ennek következtében jelentkező fokozott magzati inzulinválaszt magyarázó elméletét [18]. Az 1960-as években O’Sullivan állapította meg, hogy a terhesség során diagnosztizált szénhidrátanyagcsere-zavar növeli a későbbi életszakaszban kialakuló diabetes kockázatát, és elsóként határozta meg a GDM diagnosztikus kritériumait. Az Amerikai Egyesült Államokban 1964-ben O'Sullivan javaslatára vezették be a 100 g-os orális glükóztolerancia-tesztet várandósság alatt [19]. Randomizált, kontrollált vizsgálatot végzett 599 potenciálisan cukorbeteg és egészséges kontrollcsoportba sorolt nő körében: diétás kezelés, kis adag NPH(neutral protamine hagedorn) inzulin, valamint a rutin praenatalis gondozás hatásait hasonlította össze. A vizsgálat a 4090 g feletti testsúlyú újszülöttek számának szignifikáns csökkenését igazolta $(3,7 \%$ - rutin praenatalis gondozás vs. 4,3\% - diéta vs. 13,1\% - NPH-inzulin, $\mathrm{p}<0,05)$, de nem találtak jelentős különbséget a koraszülést és a perinatalis halálozást illetően [20]. O’Sullivan munkáját követő évtizedekben bizonytalanság volt a GDM-szűrő vizsgálatokat és a diagnosztikai vércukorszintértékeket illetően. Kontrollált vizsgálatokat végeztek, hogy bizonyítsák vagy megcáfolják a kezelés szükségességét GDM-ben. Az első többcentrumos, randomizált, kontrollált vizsgálatot 1993 és 2003 között Ausztráliában és az Egyesült Királyságban végezték (510 kontroll és 490 GDM-terhes) rizikócsoportba tartozó nők körében, valamint >7,8 mmol/1 (>140 mg/dl) egyórás 50 g-os glükózterhelési teszteredmény alapján [21]. A második többcentrumos, randomizált, kontrollált vizsgálatot 2002 és 2007 között, 16 szülészeti osztályon végezték az Amerikai Egyesült Államokban. A vizsgálatnak 7381 résztvevője volt (kizárást követően 473 kontroll és 485 GDM-terhest választottak ki), akik az alábbi kritériumoknak feleltek meg:

- 24-30. terhességi hét,

- 50 g-os glükózterhelési teszt egyórás értéke 7,5-11,1 mmol/l (135-200 mg/dl) közötti,

- ultrahangvizsgálattal igazolt terhességi hét,

1. táblázat |A gestatiós diabetes mellitus jelenleg érvényben lévő diagnosztikus kritériumai

\begin{tabular}{|c|c|c|c|c|c|c|}
\hline \multirow[t]{2}{*}{$\begin{array}{l}\text { OGTT diagnosztikus } \\
\text { plazmaglükózértékei }\end{array}$} & WHO* & ADA/IADPSG* & $\begin{array}{l}\text { ADA/Carpenter- } \\
\text { Coustan** }\end{array}$ & $\mathrm{ADA} / \mathrm{NDDG}^{* *}$ & NICE* & $\mathrm{MDT}^{*}$ \\
\hline & $75 \mathrm{~g}$ OGTT & 75 g OGTT & $100 \mathrm{~g} \mathrm{OGTT}$ & $100 \mathrm{~g} \mathrm{OGTT}$ & $75 \mathrm{~g}$ OGTT & $75 \mathrm{~g} \mathrm{OGTT}$ \\
\hline Éhomi (mmol/l) & $5,1-6,9$ & $\geq 5,1$ & $\geq 5,3$ & $\geq 5,8$ & $\geq 5,6$ & $\geq 5,6$ \\
\hline Egyórás (mmol/1) & $\geq 10,0$ & $\geq 10,0$ & $\geq 10,0$ & $\geq 10,6$ & & \\
\hline Kétórás (mmol/l) & $8,5-11,0$ & $\geq 8,5$ & $\geq 8,6$ & $\geq 9,2$ & $\geq 7,8$ & $\geq 7,8$ \\
\hline Háromórás (mmol/l) & & & $\geq 7,8$ & $\geq 8,0$ & & \\
\hline
\end{tabular}

*Egy kóros plazmaglükózérték alapján GDM diagnosztizálható.

** Legalább két kóros plazmaglükózérték alapján GDM diagnosztizálható.

$\mathrm{ADA}=$ American Diabetes Association; IADPSG = International Association of Diabetes and Pregnancy Study Groups; MDT = Magyar Diabetes Társaság; NDDG = National Diabetes Data Group; NICE = National Institute for Health and Clinical Excellence; WHO = World Health Organization. 
- kórelőzményben nem szerepel GDM, magas vérnyomás, vetélés [22].

Mindkét vizsgálat azt igazolta, hogy az orvosi táplálkozásterápia (medical nutrition therapy - MNT) és a vércukorönkontroll elősegítette a szénhidrát-anyagcsere egyensúlyban tartását.

A terhességi cukorbetegség diagnosztikájára nincs konszenzus a diabetesszel foglalkozó különböző szervezetek ajánlásaiban (1. táblázat).

\section{Az Egészségügyi Világszervezet (WHO) ajánlása}

A WHO-kritériumok a legegységesebben elfogadottak a GDM diagnózisában. Az első ajánlásokat 1965-ben publikálták, egy évvel a genfi WHO Expert Committee on Diabetes Mellitus konferenciát követően, amely az első próbálkozások egyike nemzetközi konszenzus kialakítására a diabetes mellitus klasszifikációjában. A WHO 1999-es ajánlásában közölte először a gestatiós diabetes mellitus diagnózisának kritériumait [23]. 2006-ban az 1999-ben elfogadott, GDM diagnózisában alkalmazott OGTT éhomi értékét módosították, 26,1 mmol/l-re csökkentették, ezáltal a terhesség alatt felismert emelkedett éhomi vércukorértéket (IFG) és a csökkent glükóztoleranciát (IGT) gestatiós diabetes kategóriába sorolták. A terhesség alatt felismert kóros glükóztolerancia minden esetben GDM-ként értékelendő, tekintet nélkül arra, hogy a terhelés kétórás értéke alapján diabetes mellitusnak vagy a nem terhes állapotban IGT-nek felelne meg.

A WHO 2013-as ajánlásában a terhesség alatt először felismert hyperglykaemia két csoportba sorolását javasolja:

- diabetes mellitus terhességben,

- gestatiós diabetes mellitus [24].

\section{Hyperglykaemia and Adverse Pregnancy} Outcome (HAPO) vizsgálat, International Association of Diabetes and Pregnancy Study Groups (IADPSG) Konszenzus Panel ajánlása

A világszerte ellentmondásos, nem egységes GDM-szűrési kritériumok és az 1999-es, illetve a 2006-os WHO diagnosztikai kritériumok megengedő határértékei miatt az Amerikai Nemzeti Egészségvédelmi Intézet (National Institutes of Health - NIH) és több egészségügyi szervezet nagyméretű (23 316 várandós, 18 év feletti nő) multinacionális epidemiológiai vizsgálatot végzett 2000 júliusa és 2006 áprilisa között. A HAPO vizsgálat célja a 24-28. terhességi héten végzett 75 g-os OGTT vércukorértékek és a perinatalis kimenetel közötti összefüggések felderítése volt. A HAPO megfigyelései igazolták, hogy a perinatalis szövődmények (anyai, magzati és újszülött) kockázata folyamatos növekedést mutatott a 24-28. terhességi hét között mért anyai éhomi vagy ter- helés utáni glykaemiás értékekkel a korábban normális értéktartományba sorolt szinteken, és a legtöbb kimenetelhez nem társult egyértelmû vércukor-küszöbérték [25]. Az összefüggések az anyai kortól, obesitastól, etnikai hovatartozástól és családi anamnézistől függetlenek voltak. Az alacsony rizikócsoportba tartozó nók terhességi kimenetele és tesztvércukorszintjei között is szignifikáns összefüggés van. A magzati macrosomia (az újszülött 90-es percentilis feletti születési súlya), magzati hyperinsulinaemia (90-es percentilis feletti köldökzsinórC-peptid-érték) és az újszülöttkori adipositas (90-es percentilis feletti testzsírszázalék) összefüggést mutatott az anyai enyhén (gestatiós diabetes diagnosztikus határérték alatti) emelkedett vércukorértékekkel [26]. A vizsgálat ezen eredményeit tekinthetjük a Pedersen-posztulátum utólagos megerősítésének.

A HAPO kutatói standardizált diagnosztikai módszerek bevezetését javasolták a GDM meghatározására, megfelelőbbnek tartották a diagnosztikai kritériumokat a kóros terhességi kimenetelre és nem a terhességet követő anyai diabeteskockázatra hitelesíteni. A konszenzus létrejöttének segítése céljából 2008 júniusában a kaliforniai Pasadenában az IADPSG globális konferenciát hívott össze. A konferencián bemutatott HAPO és más, szintén releváns vizsgálatok eredményeit figyelembe véve a Konszenzus Panel (IADPSG és egészségügyi szervezetek 50 tagból álló képviselői) javaslatai az alábbiak voltak:

- A 24-28. terhességi hét között minden várandósnál egylépcsős tesztet kell végezni.

- A 75 g-os OGTT egy kóros eredménye alapján GDM diagnózist kell felállítani.

- Jelzett hyperglykaemia azonosítására a terhesség korai szakaszában kritériumokat és módszereket kell kifejleszteni, a fel nem ismert diabetes miatt növekedett magzati rendellenességek és anyai szövődmények kockázatának csökkentése céljából [27].

\section{Az Amerikai Diabetes Társaság ( $A D A)$ ajánlása}

Az ADA 1998 óta szelektív szưrést javasol. 2009 januárjában ajánlotta a rizikófaktor-analízist és szükség esetén az OGTT alkalmazását. A magas rizikócsoportba tartozó nők esetében minél előbbi, a terhesség igazolását követően azonnali szürést javasol.

Magas rizikócsoport kritériumai:

- 35 év feletti anyai életkor,

- súlyos (III. fokú) elhízás: $\mathrm{BMI} \geq 40 \mathrm{~kg} / \mathrm{m}^{2}$,

- glucosuria,

- polycystás ovarium szindróma (PCOS),

- családi anamnézisben 2-es típusú cukorbetegség,

- korábbi terhességben: GDM, halott magzat, fejlődési rendellenességgel született magzat, macrosomia, nagyfokú hízás, polyhydramnion, magas vérnyomás.

Alacsony rizikócsoportba sorolható az összes alábbi jellemzőnek megfelelő terhes nő:

- 25 év alatti életkor, 
- terhesség előtt normális BMI,

- alacsony diabetes-előfordulású etnikai csoportba tartozás,

- elsőfokú rokonai között nincs cukorbeteg,

- saját kórelőzményben kóros glükóztolerancia nem szerepel,

- nincs terhelő szülészeti anamnézis.

Az ADA 2014-es és 2016-ban megjelent ajánlása nagy hangsúlyt fektet az esetlegesen már terhességet megelőzően kialakult, de még fel nem ismert 2-es típusú diabetes szűrésére az első praenatalis szülészeti vizsgálat során. A GDM szűrésére az „egylépéses” (IADPSG-konszenzus) és a „kétlépéses” stratégia alkalmazását javasolja. A terhesség korai szakaszában jelentkező kifejezett hyperglykaemia meghatározására a következő diagnosztikus értékek alkalmazását ajánlották: standardizált $\mathrm{HbA}_{\mathrm{lc}} \geq 6,5 \%$, éhomi vércukorszint $\geq 7,0 \mathrm{mmol} / 1$ vagy random plazmavércukorszint $\geq 11,1 \mathrm{mmol} / 1$. Kóros értékek esetén a laborvizsgálatok megismétlése javasolt [28].

\section{A National Institute for Health and Clinical Excellence (NICE) ajánlása}

2015 augusztusában a brit Nemzeti Intézet az Egészségért és a Klinikum Kiválóságáért frissítette a terhességi cukorbetegség diagnózisának kritériumrendszerét.

\section{A Magyar Diabetes Társaság (MDT) Diabetesszel Társuló Terhességgel Foglalkozó Munkacsoport ajánlása}

Hazánkban a 2004-ben meghozott szülészeti és belgyógyászati konszenzus alapján, a WHO által javasolt egylépcsős szürő- és diagnosztikai teszt bevezetésével kötelezővé vált a GDM teljes körü szürése. Valamennyi várandósnál a 24-28. terhességi hét között a szülészeti gondozás keretében standard 75 g-os OGTT-vizsgálatot kell végezni. A Magyar Diabetes Társaság Diabetesszel Társuló Terhességgel Foglalkozó Munkacsoportja 2015 októberében a NICE-kritériumok alkalmazása mellett döntött.

\section{A gestatiós diabetes mellitus kockázati tényezői}

Az Amerikai Egyesült Államokban több mint 200000 új GDM-es terhest diagnosztizálnak évente, amely jelentős egészségügyi és klinikai terhet jelent [29]. A 2-es típusú diabetes kialakulásának kockázata a GDM-ben szenvedó nők esetében megnövekedett [30]. A legújabb irodalmi adatok alapján a korábban GDM-mel kezelt nók esetén a macrovascularis szövődmények rizikója emelkedett a 2-es típusú diabetes kialakulásától függetlenül is [31]. Vizsgálatok azt igazolják, hogy a méhen belül GDM-nek kitett gyermekek esetében növekedik a már késői gyer- mekkorban, adolescens korban kialakuló obesitas, hypertonia és 2-es típusú diabetes kockázata [32].

Az elhízás, 25 évnél idősebb anyai életkor, családi anamnézisben szereplő 2-es típusú diabetes, valamint az előző terhesség(ek) során előforduló terhességi cukorbetegség ismert kockázati tényezők a GDM kialakulásában. GDM kialakulásának magasabb kockázatát figyelték meg egyes etnikai csoportokba tartozó nők körében. Az ázsiai, hispán és őshonos amerikai indián és afroamerikai származású nők körében magasabb a GDM előfordulásának kockázata a kaukázusi nőkhöz viszonyítva [33]. $\mathrm{Az}$ alacsonyabb testmagasságot a praegestatiós BMI-tól, életkortól és szocioökonómiai státusztól függetlenül a GDM rizikófaktoraként írták le több vizsgálatban [34].

\section{Módositható kockázati tényezők}

\section{Fizikai aktivitás}

Nem terhes populáción végzett epidemiológiai és klinikai vizsgálatokból gyưjtött evidenciák igazolják, hogy a glükóz-homeosztázis a fizikai aktivitás inzulinszenzitivitásra és -szekrécióra kifejtett direkt vagy indirekt hatásán keresztül befolyásolható. Az inzulinszenzitivitás fokozásával és a glükóztolerancia javításával, számos mechanizmuson keresztül, a fizikai aktivitásnak jótékony hatása van az inzulinrezisztencia több aspektusára [35]. Két vizsgálat a terhesség előtti és alatti fizikai aktivitás és GDM kockázatcsökkenése között pozitív összefüggést igazolt $[36,37]$. Ez a hatás fokozódik a fizikai aktivitás intenzitásának és idejének növelésével. A Nurses' Health Study II prospektív vizsgálatba 21765 , legalább egy terhességet kihordott nőt vontak be. Eredményeik 20\%-os kockázatcsökkenést igazoltak a GDM kialakulásával szemben azoknál a nőknél, akik a terhességet megelőzően naponta körülbelül 30 perc élénk sétának megfelelő erőteljes aktivitást végeztek [38]. Oken és mtsai megfigyelték, hogy a terhesség előtti fizikai aktivitás csökkentette a GDM és bármely ante partum glükózintolerancia kockázatát (44, illetve 24\%-os csökkenés) [39]. Dempsey és mtsai eset-kontroll vizsgálatukban azt találták, hogy a terhesség első 20 hetében bármilyen szabadidős fizikai aktivitásban való részvétel 48\%-kal csökkentette a GDM kockázatát [40].

\section{Étrend}

A Nurses' Health Study II vizsgálat adatai felvetették, hogy a terhesség előtti étrend összefüggésben van a terhesség alatti glükózintolerancia kialakulásának kockázatával. Ebben a nagyméretû prospektív vizsgálatban szignifikáns összefüggést figyeltek meg a nyugati, valamint az alacsony szénhidráttartalmú étrend és GDM-kockázat között [41]. Az alacsony szénhidráttartalmú étrendet gyümölcsök, zöld leveles zöldségek, baromfi és hal, míg a nyugati típusú étrendet vörös hús, feldolgozott hús, finomított gabonatermékek, édességek fogyasztása jellemezte. A terhesség előtt vörös húst fogyasztó nőket összehasonlítva, megfigyelték, hogy a heti hat adag 
1,74-szorosára emelte a GDM kockázatát a heti két adaggal szemben (relative risk [RR]: 1,74, 95\%-os konfidenciaintervallum [CI]: 1,35-2,26). A teljes kiőrlésü rostok és gabonafélék, gyümölcsrostok terhesség előtti fogyasztása szignifikáns fordított arányú kapcsolatot mutatott a GDM-kockázattal [42].

\section{Cigarettázás}

A cigarettázás összefüggést mutat a fokozott inzulinrezisztencia és a 2-es típusú diabetes kockázatának növekedésével, amint azt férfiakban és nem terhes nőkben végzett tanulmányok bizonyítják [43]. Sajnos, még mindig elég gyakori a várandós nők körében is a dohányzás, annak ellenére, hogy 8\%-os csökkenést figyeltek meg az utóbbi évtizedben. A Nurses' Health Study II a megrögzött dohányosok körében 1,43-szoros kockázatemelkedést igazolt [44].

\section{Testsúly}

A legfontosabb módosítható kockázati tényező az elhízás, tekintettel az obesitas robbanásszerüen fokozódó incidenciájára az utóbbi évtizedben a fogamzóképes korú nőkben. A GDM kockázata szignifikánsan és fokozatosan növekedik a túlsúlyos, elhízott és súlyosan elhízott nők körében. Számos - változatos populációkban végzett - tanulmány emelkedett GDM-kockázatot igazolt túlsúlyos vagy elhízott nőkben, sovány vagy normális testsúlyú nőkhöz viszonyítva. 1980 és 2006 között publikált, 20 releváns vizsgálatot összefoglaló metaanalízis eredményei azt mutatják, hogy kettő-, három- és hatszoros növekedés látható a túlsúlyos, elhízott és súlyosan elhízott nők GDM-kialakulásának kockázatában a normál testsúlyú terhes nókhöz képest (illesztett RR [95\% CI]: 1,86 [1,22-2,78], 3,34 [2,43-4,55], 5,77 [3,609,39]) [45]. A terhességet megelőző öt év során 2,3-10 kg közötti súlygyarapodás jelentős kockázatemelkedést mutatott GDM kialakulására [46]. A legújabb vizsgálatok azt igazolták, hogy $\geq 29 \mathrm{~kg} / \mathrm{m}^{3}$ BMI-vel rendelkező nők körében csak életmód-változtatással nem előzhető meg a GDM [47]. Összességében ezek az adatok azt sugallják, hogy a túlsúly és elhízás megelőzése segíthet a GDM előfordulásának csökkentésében. A terhes nők vagy terhességet tervező nők általában rendkívül motiváltak a terhesség kimenetelét javítani célzó tanácsok megfogadására, emiatt a terhesség ideje ideális időszak az egészséges életmód támogatására.

\section{Nem módositható kockázati tényezők}

A kórelőzményben szereplő GDM a 2-es típusú diabetes kialakulásának kockázatát hosszú távon növeli. Családi anamnézisben előforduló diabetes 8,5-szeres kockázatemelkedést jelent GDM vonatkozásában. Korábbi terhességben diagnosztizált GDM 30\%-os ismétlődést mutatott a következő terhességeket tekintve [48].

A GDM és a 2-es típusú diabetes mellitus patogenezisében hasonlóságok mutatkoznak, úgymint a csökkent inzulinszekréció és az inzulinrezisztencia. Ezek felvetik azt a kérdést, hogy a GDM és 2-es típusú diabetes genetikai háttere mennyiben hasonló. Ismereteink rohamos növekedését tükrözi, hogy 1998-ban egy, 2002-ben két, 2015-ben pedig már 153 génvariánst írtak le a szakirodalomban, amelyek 2-es típusú diabetesre hajlamosítanak [49].

A legújabb vizsgálatok megerősítik azt a feltételezést, hogy a GDM etiológiájában genetikai tényezők is szerepet játszanak. A kandidáns génasszociációs vizsgálatok és a teljesgenom-asszociációs vizsgálatok (genome-wide association study - GWAS) eredményeinek metaanalízise azonosított bizonyos géneket, amelyek reprodukálhatóan kapcsolatban vannak a GDM kialakulásával: TCF7L2 (transcription factor 7-like 2), GCK (glucokinase), KCNJ11 (potassium voltage-gated channel subfamily J member 11), KCNQ1 (potassium voltage-gated channel subfamily Q member 1), CDKALl (CDK5 regulatory subunit associated protein 1-like 1), IGF2BP2 (insulinlike growth factor 2 mRNA-binding protein 2), MTNRIB (melatonin receptor 1B), IRSI (insulin receptor substrate 1). Ezek a gének többségükben olyan fehérjéket kódolnak, amelyek a $\beta$-sejtek múködésében és fejlődésében szerepet játszanak, és a 2-es típusú diabetes kialakulásáért is felelősek. Az IRS1 génvariánsok ezzel szemben egy olyan dokkolófehérjét kódolnak, amelynek az inzulinszignálláncban van kulcsszerepe, és az inzulinszenzitivitást befolyásolja. A TCF7L2 transzkripciós faktor a Wnt jelátviteli út tagja, amely a HAPO vizsgálat szerint GDM-ben az egy- és kétórás vércukorszinttel, míg egy metaanalízis szerint az átlagpopulációban az éhomi vércukorszinttel mutatott szoros összefüggést. A GCK gén által kódolt glükokináz fehérje funkciója a glükóz foszforilációja $\beta$-sejtekben és hepatocytákban. A HAPO vizsgálat európai populációban az éhomi és az egyórás, thai populációban pedig a kétórás vércukorszintértékekben talált összefüggést a GCK gén GDM-re hajlamosító specifikus variánsának előfordulásával. A KCNJll és KCNQl gén által kódolt fehérje az inzulinszekréció szabályozásában vesz részt, specifikus génpolimorfizmusaik hyperglykaemiára hajlamosító hatásuk révén hozzájárulhatnak a GDM kialakulásához. A CDKALl gén a ciklinfüggő kináz $5(\mathrm{CDK} 5)$ regulátoros alegysége; az enzim a $\beta$-sejtek túlélési képességét növeli a terhességben fokozódó inzulinszekréció stressztényezője ellenében. Az IGF2BP2 gén által kódolt fehérje az IGF2 transzlációján keresztül az inzulinszekréció csökkentése irányába hat, következményes hyperglykaemiát okozva. Az MTNRIB gén által kódolt fehérje a $\beta$-sejtekben expresszálódik. A melatonin gátolja az inzulinszekréciót a $\beta$-sejteken az MTNRIB fehérje aktiválása révén [50].

\section{Következtetések}

A gestatiós diabetesnek napjainkban sincs világszerte egységesen elfogadott diagnosztikus kritériumrendszere. 
Az irodalomban leggyakrabban az Amerikai Diabetes Társaság vagy a WHO kritériumrendszerét alkalmazzák a GDM kórismézésére. A gestatiós diabetes a későbbi életkorban kialakuló cardiovascularis betegségek, 2-es típusú diabetes prediktora, a metabolikus szindróma korai manifesztációja lehet. A várandós nók döntő többsége - elsődlegesen a szülési kor kitolódása miatt - nem tartozik az alacsony kockázatú csoportba. A jelentős mértékü éhomi és étkezés utáni hyperglykaemia a korai és későbbi terhesség során összefüggésben van a magzati mortalitás és neonatalis morbiditás kockázatának fokozódásával. $\mathrm{Az}$ anyai hyperglykaemia és a következményes magzati hyperinsulinaemia központi szerepet játszik a terhességi diabetes szövődményeinek patofiziológiájában. Ezen szövődmények közé tartoznak a szülési sérülések, a császármetszések megnövekedett aránya, az újszülöttkori metabolikus komplikációk és a halvaszületés emelkedett kockázata. Az elmúlt években azonban több, nagy betegszámú obszervációs epidemiológiai, illetve randomizált kontrollált vizsgálat szolgáltatott bizonyítékot arra, hogy a GDM megfelelő kezelése javítja a terhesség kimenetelét. Több nemzetközi és egy hazai vizsgálat igazolta, hogy az IADPSG-kritériumokat alkalmazva a GDM gyakorisága megkétszereződik, az IADPSG-kritériumrendszer bevezetése következtében hatalmas teher nehezedne az egészségügyi ellátórendszerekre a felmerülő személyi és költségigények növekedése miatt. Az anyai és magzati szövődmények viszont az IADPSG-kritériumrendszer segítségével csökkenthetőek a leghatékonyabban. További vizsgálatok szükségesek a különböző kritériumrendszerek alkalmazásából adódó hosszú távú anyai és magzati előnyök és hátrányok mérlegelése céljából.

Anyagi támogatás: A közlemény a Magyar Diabetes Társaság támogatásával készült.

Szerzői munkamegosztás: A. Z.: A kézirat elkészítése. H. O., Z. A.: A kézirat javítása. R. K.: A kézirat elkészítése és javítása. R. J. Jr.: A klinikai háttér biztosítása. F. G.: A tudományos háttér biztosítása. S. A.: A klinikai és tudományos háttér biztosítása, a kézirat elkészítése és javítása. A cikk végleges változatát valamennyi szerző elolvasta és jóváhagyta.

Érdekeltségek: A szerzőknek a közleménnyel kapcsolatban nincsenek érdekeltségeik.

\section{Irodalom}

[1] Roglic, G., World Health Organization: Global report on diabetes. World Health Organization, Geneva, Switzerland, 2016.

[2] International Diabetes Federation: IDF Diabetes Atlas, 7th edn. International Diabetes Federation, Brussels, Belgium, 2015.

[3] Committee on Practice Bulletins - Obstetrics: Practice Bulletin No. 137: Gestational diabetes mellitus. Obstet. Gynecol., 2013, 122(2 Pt 1), 406-416.
[4] Kun, A., Tornoczky, J., Sudar, Z., et al.: Pregnancy outcomes of women with untreated GDM (according to the WHO 2013 diagnostic criteria). In: Abstracts of 51st EASD Annual Meeting. Diabetologia, 2015, 58(Suppl. 1.), S74.

[5] Winkler, G., Zsolnay, Cs., Hajós, P., et al.: Test breakfast or oral glucose challenge in the diagnosis of diabetes? [Tesztreggeli vagy orális glukózterhelés a gesztátiós diabetes mellitus kórismézésében?] Magy. Belorv. Arch., 1995, 48(3), 169-171. [Hungarian]

[6] Egyed, J., Csákány, M. Gy., Oláh, J., et al.: Theoretical questions regarding the care of pregnancy complicated with diabetes (from obstetrical point of view). [A cukorbetegséggel szövődött terhesség gondozásának elvi kérdései (szülészeti szempontok).] Magyar Nóorvosok Lapja, 1996, 59(6), 449-452. [Hungarian]

[7] Pátkay, J., Varga Szabó L., Medve, L.: Screening of gestational diabetes in Dunaújváros. Results and experiences of 10 years. [Gesztációs diabetes szúrés Dunaújvárosban. Tíz év eredményei, tapasztalatai.] Magy. Belorv. Arch., 1997, 50(6), 635-639. [Hungarian]

[8] Baranyi, É.: Diabetes and pregnancy. In: Baranyi, É., Békefi, D., Fövényi, J. (eds.): Diabetes mellitus - Facts and datas). [Diabétesz és terhesség. In: Baranyi, É., Békefi, D., Fövényi, J. (szerk.): Diabetes mellitus - Tények és adatok.] Melánia Kiadó, Budapest, 1998. 185-198. [Hungarian]

[9] Kerényi, Z., Bosnyák, Zs., Péterfalvi, A.: Prevalence of gestational diabetes mellitus: three years results of a Hungarian validated, full spectrum screening programme. [A gesztációs diabetes előfordulási gyakorisága: validált, teljes körű hazai szűrés hároméves eredményei.] Magy. Belorv. Arch., 2011, 64(6), 349-356. [Hungarian]

[10] Kun, A.: Incidence of gestational diabetes in Tolna county in 2000. [Gestatiós diabetes előfordulása Tolna megyében 2000ben.] Diabetol. Hung., 2006, 14, 235-240. [Hungarian]

[11] Tamas, G., Kerenyi, Z.: Gestational diabetes: current aspects on pathogenesis and treatment. Exp. Clin. Endocrinol. Diabetes, 2001, 109 (Suppl. 2), S400-S411.

[12] Kevényi, Zs., Péterfalvi, A., Bosnyák, Zs., et al.: Incidence of gestational diabetes based on a validated extensive screening. [A gestatios diabetes incidenciája alapján validált teljes körü szúrés.] Diabetol. Hung., 2004, 12(Suppl. 1), 72. [Hungarian]

[13] Ferrara, A.: Increasing prevalence of gestational diabetes mellitus: a public health perspective. Diabetes Care, 2007, 30(Suppl. 2), S141-S146.

[14] Sun, W. J., Yang, H. X.: Maternal and fetal outcomes in pregnant women with abnormal glucose metabolism. Zhonghua Fu Chan Ke Za Zhi, 2007, 42(6), 377-381. [Article in Chinese]

[15] Hadden, D. R., Hillebrand, B.: The first recorded case of diabetic pregnancy (Bennewitz HG, 1824, University of Berlin). Diabetologia, 1989, 32(8), 625.

[16] Negrato, C. A., Gomes, M. B.: Historical facts of screening and diagnosing diabetes in pregnancy. Diabetol. Metab. Syndr., $2013,5,22$.

[17] Gilbert, J. A., Dunlop, D. M.: Diabetic fertility, maternal mortality, and foetal loss rate. Br. Med. J., 1949, 1(4592), 48-51.

[18] Pedersen, J., Osler, M.: Hyperglycemia as the cause of characteristic features of the foetus and newborn of diabetic mothers. Dan. Med. Bull., 1961, 8, 78-83.

[19] O'Sullivan, J. B., Mahan, C. M.: Criteria for the oral glucose tolerance test in pregnancy. Diabetes, 1964, 13, 278-285.

[20] O'Sullivan, J. B., Gellis, S. S., Dandrow, R. V., et al.: The potential diabetic and her treatment in pregnancy. Obstet. Gynecol., 1966, 27(5), 683-689.

[21] Crowther, C. A., Hiller, J. E., Moss, J. R., et al.: Effect of treatment of gestational diabetes mellitus on pregnancy outcomes. N. Engl. J. Med., 2005, 352(24), 2477-2486.

[22] Landon, M. B., Spong, C. Ү., Thom, E., et al.: A multicenter, randomized trial of treatment for mild gestational diabetes. N. Engl. J. Med., 2009, 361(14), 1339-1348. 
[23] Definition, diagnosis and classification of diabetes mellitus and its complications: Report of a WHO Consultation. Part I: Diagnosis and classification of diabetes mellitus. WHO/NCD/ NCS/99.2., World Health Organization, Geneva, 1999.

[24] Diagnostic criteria and classification of hyperglycaemia first detected in pregnancy: a World Health Organization Guideline. Diabetes Res. Clin. Pract., 2014, 103(3), 341-363.

[25] The HAPO Study Cooperative Research Group, Metzger, B. E., Lowe, L. P., Dyer, A. R., et al.: Hyperglycemia and adverse pregnancy outcomes. N. Engl. J. Med., 2008, 358(19), 1991-2002.

[26] Gibler, W. B., Blomkalns, A. L.: Achieving standardization in clinical research: changing cacophony into harmony. Ann. Emerg. Med., 2004, 44(3), 213-214.

[27] International Association of Diabetes and Pregnancy Study Groups Consensus Panel, Metzger, B. E., Gabbe, S. G., Persson, B., et al.: International Association of Diabetes and Pregnancy Study Groups recommendations on the diagnosis and classification of hyperglycemia in pregnancy. Diabetes Care, 2010, 33(3), 676682.

[28] American Diabetes Association: 12. Management of diabetes in pregnancy. Diabetes Care, 2016, 39(Suppl. 1), S94-S98.

[29] American Diabetes Association: 2. Classification and diagnosis of diabetes. Diabetes Care, 2016, 39(Suppl. 1), S13-S22.

[30] Kim, C., Newton, K. M., Knopp, R. H.: Gestational diabetes and the incidence of type 2 diabetes: a systematic review. Diabetes Care, 2002, 25(10), 1862-1868.

[31] Retnakaran, R., Shah, B. R.: Role of type 2 diabetes in determining retinal, renal, and cardiovascular outcomes in women with previous gestational diabetes mellitus. Diabetes Care, 2017, 40(1), 101-108. [Epub 2016 Nov 7]

[32] Dabelea, D., Mayer-Davis, E. J., Lamichhane, A. P., et al.: Association of intrauterine exposure to maternal diabetes and obesity with type 2 diabetes in youth: the SEARCH Case-Control Study. Diabetes Care, 2008, 31(7), 1422-1426.

[33] Savitz, D. A., Janevic, T. M., Engel, S. M., et al.: Ethnicity and gestational diabetes in New York City, 1995-2003. BJOG, 2008, 115(8), 969-978.

[34] Branchtein, L., Schmidt, M. I., Matos, M. C., et al.: Short stature and gestational diabetes in Brazil. Brazilian Gestational Diabetes Study Group. Diabetologia, 2000, 43(7), 848-851.

[35] Helmrich, S. P., Ragland, D. R., Leung, R. W., et al.: Physical activity and reduced occurrence of non-insulin-dependent diabetes mellitus. N. Engl. J. Med., 1991, 325(3), 147-152.

[36] Retnakaran, R., Qi, Y., Sermer, M., et al.: Pre-gravid physical activity and reduced risk of glucose intolerance in pregnancy: the role of insulin sensitivity. Clin. Endocrinol. (Oxf.), 2009, 70(4), 615-622.

[37] Liu, J., Laditka, J. N., Mayer-Davis, E. J., et al.: Does physical activity during pregnancy reduce the risk of gestational diabetes among previously inactive women? Birth, 2008, 35(3), 188-195.
[38] Zhang, C., Solomon, C. G., Manson, J. E., et al.: A prospective study of pregravid physical activity and sedentary behaviors in relation to the risk for gestational diabetes mellitus. Arch. Intern. Med., 2006, 166(5), 543-548.

[39] Oken, E., Ning, Y., Rifas-Shiman, S. L., et al.: Associations of physical activity and inactivity before and during pregnancy with glucose tolerance. Obstet. Gynecol., 2006, 108(5), 1200-1207.

[40] Dempsey, J. C., Butler, C. L., Sorensen, T. K., et al.: A case-control study of maternal recreational physical activity and risk of gestational diabetes mellitus. Diabetes Res. Clin. Pract., 2004, 66(2), 203-215.

[41] Zhang, C., Schulze, M. B., Solomon, C. G., et al.: A prospective study of dietary patterns, meat intake and the risk of gestational diabetes mellitus. Diabetologia, 2006, 49(11), 2604-2613.

[42] Zhang, C., Liu, S., Solomon, C. G., et al.: Dietary fiber intake, dietary glycemic load, and the risk for gestational diabetes mellitus. Diabetes Care, 2006, 29(10), 2223-2230.

[43] Rimm, E. B., Manson, J. E., Stampfer, M. J., et al.: Cigarette smoking and the risk of diabetes in women. Am. J. Public Health, 1993, 83(2), 211-214.

[44] Solomon, C. G., Willett, W. C., Carey, V. J., et al.: A prospective study of pregravid determinants of gestational diabetes mellitus. JAMA, 1997, 278(13), 1078-1083.

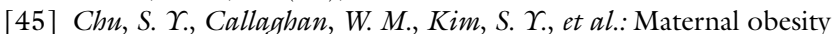
and risk of gestational diabetes mellitus. Diabetes Care, 2007, 30(8), 2070-2076.

[46] Hedderson, M. M., Williams, M. A., Holt, V. L., et al.: Body mass index and weight gain prior to pregnancy and risk of gestational diabetes mellitus. Am. J. Obstet. Gynecol., 2008, 198(4), 409. el-409.e7.

[47] Simmons, D., Devlieger, R., van Assche, A., et al.: Effect of physical activity and/or healthy eating on GDM risk: The DALI Lifestyle Study. J. Clin. Endocrinol. Metab., 2016 Dec 9. jc20163455. [Epub ahead of print]

[48] Williams, M. A., Qiu, C., Dempsey, J. C., et al.: Familial aggregation of type 2 diabetes and chronic hypertension in women with gestational diabetes mellitus. J. Reprod. Med., 2003, 48(12), 955-962.

[49] Prasad, R. B., Groop, L.: Genetics of type 2 diabetes-pitfalls and possibilities. Genes (Basel), 2015, 6(1), 87-123.

[50] Lowe, W. L. Jr., Scholtens, D. M., Sandler, V., et al.: Genetics of gestational diabetes mellitus and maternal metabolism. Curr. Diab. Rep., 2016, 16(2), 15.

(Al-Aissa Zahra dr., Budapest, Szentkirályi utca 46., 1088 e-mail: alaissazahra@yahoo.com)

Seris venit usus ab annis. (Míg elfut sok idő, a tapasztalat eljő.) 